Regards sur l'économie allemande

Bulletin économique du CIRAC

$111 \mid 2013$

Varia

\title{
Histoire de la presse
}

EVENO Patrick, Histoire de la presse française - de Théophraste

Renaudot à la révolution numérique

\section{(2) OpenEdition}

Journals

Édition électronique

URL : http://journals.openedition.org/rea/4637

DOI : $10.4000 /$ rea.4637

ISSN : 1965-0787

Éditeur

CIRAC

Édition imprimée

Date de publication : 1 décembre 2013

Pagination : 39-40

ISSN : 1156-8992

Référence électronique

"Histoire de la presse », Regards sur l'économie allemande [En ligne], 111 | décembre 2013, mis en ligne le 17 décembre 2013, consulté le 22 septembre 2020. URL : http://journals.openedition.org/rea/4637 DOI : https://doi.org/10.4000/rea.4637

Ce document a été généré automatiquement le 22 septembre 2020

(C) CIRAC 


\section{Histoire de la presse}

EVENO Patrick, Histoire de la presse française - de Théophraste

Renaudot à la révolution numérique

\section{RÉFÉRENCE}

EVENO Patrick, Histoire de la presse française - de Théophraste Renaudot à la révolution numérique, Flammarion, Paris, 2012, 272 p.

Ce beau livre, richement illustré, se propose de retracer l'histoire de la presse française, depuis l'invention par Gutenberg de la presse à imprimer en 1434 et la création de la Gazette de Renaudot en 1631 jusqu'à nos jours. Née réellement au XVII ${ }^{\mathrm{e}}$ siècle autour des riches régions de Londres, Paris, Florence, Anvers et Francfort, dans un environnement d'échanges de marchandises et d'idées, la presse crée un espace public «consubstantiel à la démocratie ». Or la démocratie, combinée à l'alphabétisation et à l'industrialisation, jettera les bases de l'âge d'or de la presse française, à la veille de la Première Guerre mondiale. Un regard utile sur les évolutions de ce média aujourd'hui fortement concurrencé, entre crise et renouveau. (sh) 